\title{
II. Heat stress in Triticum: kinetics of Cu and $\mathrm{Zn}$ accumulation
}

\author{
Ana S. Dias ${ }^{1,2^{*}}$ and Fernando C. Lidon ${ }^{1}$
}

${ }^{1}$ Grupo de Disciplinas de Ecologia da Hidrosfera, Faculdade de Ciências e Tecnologia, Universidade Nova de Lisboa, Quinta da Torre, 2829-516 Caparica, Portugal.

${ }^{2}$ Instituto Nacional de Investigação Agrária, Instituto Nacional dos Recursos Biológicos, I.P., Estrada de Gil Vaz, Elvas, Portugal.

*Corresponding author: Phone/Fax: 00351212948543; anasofia.almeida@mail.com Received: 31 July 2009; Accepted: 29 October 2009

\section{ABSTRACT}

The interactions between high temperatures and $\mathrm{Cu} / \mathrm{Zn}$ accumulation were investigated in bread and durum wheat. Plants were grown in a greenhouse, at two different temperatures regimes (control $-25 / 14^{\circ} \mathrm{C}$ and heat stress $-31 / 20^{\circ} \mathrm{C}$ ), and the contents and uptake/translocation of $\mathrm{Cu}$ and $\mathrm{Zn}$ were evaluated during three developmental stages of plant growth (booting, grain filling and maturity). During grain filling and at maturity it was found that root, shoot and spike concentrations of $\mathrm{Cu}$ increased in heat stressed plants of the genotypes Golia and Acalou. The same trend was observed for root and shoot concentrations of Zn in both durum wheat genotypes. It was concluded that plants submitted to high temperatures (during the grain filling period) become more efficient in the Cu translocation to the shoots.

Key words: Triticum aestivum L. - Triticum turgidum subsp. Durum - heat stress - uptake - nutrients translocation.

\section{INTRODUCTION}

Temperature and nutrition are two major components of environmental variation that provide significant limitations to a successful crop production. During the crops growth cycle, the optimal mean temperature might vary between $15-18^{\circ} \mathrm{C}$ (Chowdhury and Wardlaw, 1978), being $20^{\circ} \mathrm{C}$ the optimal value for grain filling (Jenner, 1991; Dupond and Altenbach, 2003). Several studies conducted in Australia and USA further indicated that a decreased of about $10-15 \%$ in crop production occur each year, mostly due to high temperatures during anthesis (Wardlaw and Wrigley, 1994). It was also pointed by Wardlaw et al. (1989) that a global reduction in crops production of about $3-4 \%$ occurs when the temperature increases by $1^{\circ} \mathrm{C}$ (i.e., mean temperatures above optimum). When water is not a limiting factor, Triticum productions with late sowing in Mediterranean environments (thus, with high temperatures in the end of the cycle) also have lower yields, mostly as a result of heat stress during grain filling (Maçãs et al., 2000). In this context, Sofield et al. (Sofield et al., 1977) showed that increasing temperatures during grain filling (between $15 / 10^{\circ} \mathrm{C}$ and $21 / 16^{\circ} \mathrm{C}$, day/night temperatures), counterbalances the diminished growth duration, increasing the filling rate (although, only triggering a small variation of the grain weight). With higher temperatures, ranging between $21 / 16^{\circ} \mathrm{C}$ and $30 / 25^{\circ} \mathrm{C}$ (day/night temperatures), these authors showed that the grain filling rate did not display a compensatory increase when correlated with its duration period (thus, inducing a significant reduction of the grain weight at maturity). It has been referred that high temperatures, within defined values, increase the rate of mitosis, counterbalancing its decreased duration (Nicolas et al., 1984). Yet, at a cellular 
level, although about $80 \%$ of cellular enlargement occurs between the end of cellular division and the conclusion of dry matter accumulation (Nicolas et al., 1984), the rate of cellular volumetric augmentation does not compensate the decreasing extent of cellular enlargement (Stone et al., 1995. Caley et al. (1990) and Jenner (1994) further confirmed these data, and Shpiler and Blum (1986), working with field trials, also reported that grain maturity develops earlier, producing smaller and shriveled grains, in heat stressed genotypes.

Cu and Zn are microelements with important physiological functions in plants that act synergistically in wheat (Khurama and Chatterjee, 2000), however, at high concentrations it can become toxic, thus leading to physiological and morphological disturbances and, eventually to a decreased yield (Agrawal and Sharma, 2006). Considering the high mobility of $\mathrm{Cu}$ and $\mathrm{Zn}$ in plant tissues, as well as their metabolic functions during growth (for review see Marschner, 1995), the cationic status of $\mathrm{Cu}$ and $\mathrm{Zn}$, during the life cycle of heat stressed bread and durum wheat is characterized in this work. In this context, the uptake and translocation kinetics from roots to the aerial part is additionally discussed, using as a test system two genotypes of Triticum aestivum (Sever from Portugal and Golia from Italy) and of Triticum turgidum subsp. turgidum (TE 9306 from Portugal and Acalou from France), integrating different genomic characteristics (Dias and Lidon, 2009), with different tolerance to high temperature after anthesis (Maçãs et al., 2000), were used as test systems.

\section{MATERIALS AND METHODS}

Plant material and growth conditions: Bread wheat (Triticum aestivum L. genotypes Sever and Golia) and durum wheat (Triticum turgidum subsp. durum genotypes TE 9306 and Acalou) grains were washed in distilled water and sterilized by immersion in mercury dichloride solution (1:1000) for 2 minutes. The grains were next washed five times in deionizer water and placed in an oven at $28^{\circ} \mathrm{C}$ for 24 hours. Immediately thereafter the seeds were grown in a greenhouse (under natural light, between March and May in Lisbon/Portugal - $38^{\circ} 42^{\prime}$ N; $9^{\circ} 05^{\prime}$ W; photoperiod varying between 12 and 14 hours) in $25 \times 21 \mathrm{~cm}$ pots containing a 1:1 perlite and vermiculite mixture. The experiment was conducted using 136 pots. Half of these pots were putted under heat stress after anthesis. For each genotype 17 replicates were used (with and without heat stress). Ten seeds were grown per pot and two weeks later five were selected, being the others removed. Accordingly, 680 plants were used. In each plant all tillers were removed, keeping only the main culm. During all the experiment the position of the pots was changed weekly, to minimize the effects due to irradiance variations. Plants were irrigated weakly but alternatively with distillated water or with a standard nutrient solution, alternately (in $\mathrm{ml} / 100 \mathrm{~L}$, starter/pre-anthesis/postanthesis, $\mathrm{Ca}\left(\mathrm{NO}_{3}\right)_{2}$ 100/100/50; $\mathrm{KNO}_{3} 50 / 200 / 100 ; \mathrm{KH}_{2} \mathrm{PO}_{4}$ 100/100/100; $\mathrm{MgSO}_{4}$ 200/200/100; $\mathrm{K}_{2} \mathrm{SiO}_{3}$ 100/100/0; $\mathrm{Fe}\left(\mathrm{NO}_{3}\right)_{3} 2 \mathrm{O} / 5 / 5 ; \mathrm{EDTA} 25 / 5 / 5 ; \mathrm{MnCl}_{2} 5 / 10 / 5 ; \mathrm{ZnSO}_{4} 20 / 10 / 10$; $\mathrm{H}_{3} \mathrm{BO}_{3}$ 10/5/2; $\left.\mathrm{CuSO}_{4} 5 / 5 / 3 ; \mathrm{Na}_{2} \mathrm{MoO}_{4} 15 / 5 / 5\right)$. During the vegetative and reproductive growth, plants were kept under similar environment conditions. At anthesis, the plants were divided in two groups and submitted to two different temperature conditions (controlled and heat stress). Under heat stress the plants were submitted to temperatures that rose until $40^{\circ} \mathrm{C}$. During the grain filling period, control plants grew under regimes with mean temperatures (day/night) of $25 / 14^{\circ} \mathrm{C}$ and $31 / 20^{\circ} \mathrm{C}$ (control and heat stress conditions, respectively). The average of day/night temperatures was calculated as the mean readings of each two hours, during each 24 hours period.

Nutrients analysis: The concentrations of $\mathrm{Cu}$ and $\mathrm{Zn}$ were determined in roots, shoots and spikes (at booting 69/70 days after anthesis; grain filling - 108/109 and 109/112 days after anthesis, for the genotypes submitted to control and heat stress conditions, respectively) and also in the grain, at maturity. Five randomized plants of each genotype, from each heat treatment, were used for nutrients analysis. Plant samples were washed, the fresh weight was determined in each fraction and, therefore, dry weight was measured after dryness in an oven for $100^{\circ} \mathrm{C}$ during $72 \mathrm{~h}$. One gram of dry material, from each sample, was mineralized through incineration at c.a. $550^{\circ} \mathrm{C}$, and followed by nitric acid digestion (Vandecasteele and Block, 1993). A Unicam model 939 absorption unit, equipped with a hollow cathode lamp was used for $\mathrm{Cu}$ and $\mathrm{Zn}$, determinations. The mean concentration values of the nutrients and biomass yields of the roots, shoots and spikes (and grain weight for the grains) were used to determine the related mean content in all Triticum roots, shoots and grains. The net uptake was determined adding these values. 
Statistical analysis: Statistic analysis were performed with a two-way ANOVA ( $p \leq 0.05)$, using STATISTICA, version 6 (2001), by StatSoft, Inc. In figures, each value is the mean \pm S.E. of three replicates and letters $a$ and $b$ stands for significant different means. In tables, different letters in the same column refer to significant differences between genotypes. Between treatments, ns, * ${ }^{* *}$ and ${ }^{* * *}$ refer to: non significant, $\mathrm{P} \leq$ $0.05, P \leq 0.01$ and $P \leq 0.001$, respectively.

\section{RESULTS AND DISCUSSION}

The effects of heat stress after anthesis can integrate plant responses to periods with moderate high temperatures $\left(25 / 32^{\circ} \mathrm{C}\right)$ (Chinoy, 1947; Wardlaw et al., 1989) and plant behaviors to short periods with high temperatures (higher than $32^{\circ} \mathrm{C}$ ) (Randall and Moss, 1990; Blumenthal et al., 1991). In a previous study, our research group, working on heat stress after anthesis (Maçãs et al., 2000; Dias et al., 2008, 2009; Dias and Lidon, 2009), found that Triticum aestivum L. genotype Sever is more tolerant than the genotype Golia and that Triticum turgidum subsp. durum genotype TE 9306 tolerance prevailed relatively to the genotype Acalou. Under the defined heat stress conditions, it was found that $\mathrm{Cu}$ concentrations in roots, during booting and grain filling, were similar in all genotypes (Table 1) yet, at maturity bread and durum wheat genotypes showed significant differences. This effect can be linked to the ionic status of $\mathrm{Cu}$ that in vivo might occur with different oxidation states. In this context, these contents (Table 1) were significantly higher in Golia ( $57 \%$ relatively to Sever), with a similar pattern being revealed with TE 9306 (1.25 fold when compared with Acalou). During booting, Cu contents in the shoot varied between $5.5-8.9 \mu \mathrm{g} / \mathrm{g}$, values quite similar to these allocated, as a general pattern, by Bergmann (1992) for Triticum. At maturity, the concentrations of $\mathrm{Cu}$ in the shoots of Golia in control conditions (Table 1) were lower (although non-significant) when compared with the heat stressed plants. A similar pattern was found for Acalou (Table 1), but the difference was significant (30\% in the control relatively to the stressed plants). The results found for these genotypes were also consistent with those reported by Davis et al. (1984) for Triticum, which pointed values ranging between $1-14 \mu / \mathrm{g}$ in experiments conducted with 231 cultivars (obtained in 49 difference growth sites). The major assertion of this work is that under heat stress, the increased levels of
Cu did not reached the threshold of toxicity, values that have previously been consider as varying between 20-30 $\mu \mathrm{g} / \mathrm{g}$ (Kabata-Pendias and Pendias, 1992). As a general pattern it was further noticed that $\mathrm{Cu}$ contents increased in the different parts of the heat stressed plants (Table 1), following patterns also reported by Garnett and Graham (2005), excepting TE 9306 during grain filling (which decreased in all the analyzed parts of the plants, displaying significantly low levels in the spike).

Following the applied heat stress, in the three growth phases (excepting at maturity), the levels of $Z n$ in the roots, which is mostly absorbed in the dicationic form, of the bread wheat genotypes, were higher than those of durum wheat (Table 2). As also seen by Pearson and Rengel (1994), this trend didn't occur in the shoots, being a consistent drop detected during the plant cycle, which eventually became a sign of membrane permeability alteration. The mean values for $\mathrm{Zn}$ concentration in the control plants of durum wheat were 148, 101 and $46 \mu \mathrm{g} / \mathrm{g}$, being for bread wheat 142, 123 and $79 \mu / \mathrm{g}$ (Table 2). As a general trend, the concentration of Zn in the roots of both Triticum species was affected during all the life cycle by heat stress (Table 2), probably indicating an higher membrane potential (Marschner, 1995). Accordingly, during grain filling, Zn contents in the roots of Golia and Acalou (Table 2) were about four fold higher than those measured in the control plants which, in spite of some controversy (Moore, 1972), is most likely metabolically controlled. The increase of $\mathrm{Zn}$ concentration in the shoots become significant only in Acalou (during grain filling) and TE 9306 (at maturity), which further point, as previously reported by Yläranta et al. (1979) and Garnett and Graham (2005), a prevalent stabilization on Zn contents in Triticum. In the spike, the heat stress did not affect significantly the levels of Zn (Table 2), persisting as previously reported (Wheeler and Power, 1995) asymptotic plant concentrations. During booting, probably indicating a high capacity to synthesize stable complexes, the concentration of Zn did not changed significantly between durum wheat genotypes, and in bread wheat genotypes only the shoots levels of $\mathrm{Zn}$ varied (Table 2), although persisting within the limits of non-phytoxicity (Marschner, 1995). Moreover, under heat stress, during grain filling, the root $\mathrm{Zn}$ status was significantly different relatively to those found for Sever (Table 2). 
Table 1. Copper concentration $(\mu \mathrm{g} / \mathrm{g})$ in different plant parts, on three stages of plant growth (booting, grain filling and maturity), of control and heat stress bread and durum wheat genotypes.

\begin{tabular}{|c|c|c|c|c|c|}
\hline & \multirow[t]{2}{*}{ Booting } & \multicolumn{2}{|c|}{ Grain filling } & \multicolumn{2}{|c|}{ Maturity } \\
\hline & & Control & Heat stress & Control & Heat stress \\
\hline \multicolumn{6}{|c|}{ Root } \\
\hline Golia & $10.25 \pm 0.43 a$ & $9.05 \pm 0.42 \mathrm{a}$ & $17.26 \pm 1.79 \mathrm{a}$ * & $14.15 \pm 0.89 a$ & $15.16 \pm 0.91 \mathrm{a} n s$ \\
\hline Sever & $10.95 \pm 1.01 \mathrm{a}$ & $7.39 \pm 0.05 a$ & $11.43 \pm 0.05 a^{* * *}$ & $8.22 \pm 0.01 b$ & $9.04 \pm 0.09 b$ * \\
\hline Bread wheat & $10.60 \pm 0.49$ & $8.22 \pm 0.51$ & $14.34 \pm 1.83$ ** & $11.18 \pm 1.75$ & $12.10 \pm 1.80 \mathrm{~ns}$ \\
\hline Acalou & $10.53 \pm 2.44 a$ & $9.27 \pm 0.81 a$ & $13.04 \pm 0.14 a$ * & $10.73 \pm 0.01 a$ & $12.13 \pm 0.34 \mathrm{a}$ ns \\
\hline TE 9306 & $9.47 \pm 1.56 \mathrm{a}$ & $17.91 \pm 2.18 \mathrm{a}$ & $15.88 \pm 0.85 a \mathrm{~ns}$ & $13.42 \pm 0.21 b$ & $14.09 \pm 0.23 \mathrm{bns}$ \\
\hline Durum wheat & $10.00 \pm 1.22$ & $13.59 \pm 2.67$ & $14.46 \pm 0.89 \mathrm{~ns}$ & $12.07 \pm 0.78$ & $13.11 \pm 0.59$ * \\
\hline \multicolumn{6}{|c|}{ Shoot } \\
\hline Golia & $8.92 \pm 0.12 a$ & $3.77 \pm 0.40 \mathrm{a}$ & $4.31 \pm 0.14 \mathrm{a} n \mathrm{~s}$ & $2.24 \pm 0.00 \mathrm{a}$ & $14.43 \pm 3.22 \mathrm{ans}$ \\
\hline Sever & $8.60 \pm 0.10 a$ & $3.80 \pm 0.03 a$ & $4.40 \pm 0.12 \mathrm{a}$ * & $4.78 \pm 1.46 a$ & $3.91 \pm 0.02 \mathrm{a} n \mathrm{~s}$ \\
\hline Bread wheat & $8.76 \pm 0.11$ & $3.78 \pm 0.16$ & $4.35 \pm 0.08 \mathrm{~ns}$ & $3.51 \pm 0.94$ & $9.17 \pm 3.31$ * \\
\hline Acalou & $5.46 \pm 0.36 a$ & $3.50 \pm 0.19 a$ & $6.33 \pm 2.69 \mathrm{a} n \mathrm{~s}$ & $4.05 \pm 0.72 a$ & $13.63 \pm 1.61 \mathrm{a}$ * \\
\hline TE 9306 & $7.58 \pm 0.25 b$ & $7.20 \pm 1.69 \mathrm{a}$ & $5.26 \pm 0.08 \mathrm{a} n \mathrm{~ns}$ & $3.81 \pm 0.17 a$ & $5.94 \pm 0.45 b$ * \\
\hline Durum wheat & $6.52 \pm 0.64$ & $5.35 \pm 1.27$ & $5.79 \pm 1.14 \mathrm{~ns}$ & $3.93 \pm 0.31$ & $9.79 \pm 2.32$ ** \\
\hline \multicolumn{6}{|c|}{ Spike } \\
\hline Golia & & $2.87 \pm 0.01 \mathrm{a}$ & $4.39 \pm 0.10 \mathrm{a} * *$ & $4.40 \pm 0.21 \mathrm{a}$ & $7.25 \pm 1.11 \mathrm{a} n \mathrm{~s}$ \\
\hline Sever & & $2.84 \pm 0.20 \mathrm{a}$ & $3.99 \pm 0.38 \mathrm{a} n \mathrm{~s}$ & $2.72 \pm 0.00 \mathrm{~b}$ & $3.17 \pm 0.11 \mathrm{a} n \mathrm{~s}$ \\
\hline Bread wheat & & $2.85 \pm 0.08$ & $4.19 \pm 0.20$ ** & $3.56 \pm 0.49$ & $5.21 \pm 1.26$ * \\
\hline Acalou & & $4.62 \pm 0.07 a$ & $7.34 \pm 0.19 a * \star$ & $3.13 \pm 0.22 \mathrm{a}$ & $8.40 \pm 1.65 a \mathrm{~ns}$ \\
\hline TE 9306 & & $6.60 \pm 0.19 b$ & $4.28 \pm 0.41 b$ * & $5.05 \pm 0.18 b$ & $5.80 \pm 0.17 \mathrm{a} n \mathrm{~s}$ \\
\hline Durum wheat & & $5.61 \pm 0.58$ & $5.81 \pm 0.90 \mathrm{~ns}$ & $4.09 \pm 0.56$ & $7.10 \pm 1.01$ * \\
\hline & & & & \multicolumn{2}{|c|}{ Grain } \\
\hline Golia & & & & $3.99 \pm 0.41 \mathrm{a}$ & $4.11 \pm 0.56 \mathrm{a} n \mathrm{~s}$ \\
\hline Sever & & & & $2.98 \pm 0.14 a$ & $3.53 \pm 0.26 \mathrm{a} n \mathrm{~s}$ \\
\hline Bread wheat & & & & $3.49 \pm 0.34$ & $3.82 \pm 0.30 \mathrm{~ns}$ \\
\hline Acalou & & & & $3.21 \pm 0.59 a$ & $4.65 \pm 0.17 \mathrm{a}$ ns \\
\hline TE 9306 & & & & $3.96 \pm 0.19 a$ & $4.70 \pm 0.03 \mathrm{a} n \mathrm{~ns}$ \\
\hline Durum wheat & & & & $3.58 \pm 0.33$ & $4.67 \pm 0.07$ * \\
\hline
\end{tabular}

Note: Each value is the mean \pm S.E. of three replicates. Different letters in the same column refer to significant differences between genotypes. Between treatments, ns, ${ }^{*}{ }^{* *}$ and ${ }^{* * *}$ refer to: non significant, $P \leq 0.05, P \leq 0.01$ and $P \leq 0.001$, respectively. 
Table 2. Zinc concentration $(\mu \mathrm{g} / \mathrm{g})$ in different plant parts, on three stages of plant growth (booting, grain filling and maturity), of control and heat stress bread and durum wheat genotypes.

\begin{tabular}{|c|c|c|c|c|c|}
\hline & \multirow[t]{2}{*}{ Booting } & \multicolumn{2}{|c|}{ Grain filling } & \multicolumn{2}{|c|}{ Maturity } \\
\hline & & Control & Heat stress & Control & Heat stress \\
\hline \multicolumn{6}{|c|}{ Root } \\
\hline Golia & $178.56 \pm 21.21 \mathrm{a}$ & $93.71 \pm 4.46 \mathrm{a}$ & $361.91 \pm 42.23 \mathrm{a}$ * & $93.23 \pm 18.18 a$ & $131.94 \pm 19.20 \mathrm{a} n \mathrm{~s}$ \\
\hline Sever & $135.93 \pm 2.16 a$ & $178.02 \pm 35.34 a$ & $161.20 \pm 5.66 \mathrm{~b} n s$ & $79.28 \pm 0.85 a$ & $175.41 \pm 1.91 \mathrm{a} * \star *$ \\
\hline Bread wheat & $157.25 \pm 15.07$ & $135.86 \pm 28.35$ & $261.56 \pm 60.49$ * & $86.26 \pm 8.45$ & $153.67 \pm 14.82$ ** \\
\hline Acalou & $113.92 \pm 16.20 \mathrm{a}$ & $35.42 \pm 1.58 \mathrm{a}$ & $133.10 \pm 1.42 \mathrm{a} * \star \star$ & $76.29 \pm 4.23 a$ & $209.76 \pm 6.05 a * \star$ \\
\hline TE 9306 & $89.53 \pm 15.42 \mathrm{a}$ & $107.83 \pm 26.76 a$ & $134.44 \pm 1.42 \mathrm{a} n s$ & $76.76 \pm 3.76 \mathrm{a}$ & $161.93 \pm 4.47 \mathrm{~b} * *$ \\
\hline Durum wheat & $101.72 \pm 11.53$ & $71.63 \pm 23.60$ & $133.27 \pm 0.83$ * & $76.52 \pm 2.31$ & $185.85 \pm 14.14$ *** \\
\hline \multicolumn{6}{|c|}{ Shoot } \\
\hline Golia & $119.75 \pm 6.98 a$ & $129.04 \pm 13.22 \mathrm{a}$ & $123.80 \pm 5.65 \mathrm{a} n \mathrm{~s}$ & $61.05 \pm 5.32 \mathrm{a}$ & $112.15 \pm 17.82 \mathrm{a} n \mathrm{~s}$ \\
\hline Sever & $163.75 \pm 4.02 b$ & $116.65 \pm 11.17 a$ & $97.58 \pm 5.78 \mathrm{a} n s$ & $97.11 \pm 0.92 b$ & $105.13 \pm 4.59 \mathrm{a} n s$ \\
\hline Bread wheat & $141.63 \pm 13.05$ & $122.84 \pm 7.92$ & $110.69 \pm 8.26 \mathrm{~ns}$ & $79.08 \pm 10.64$ & $108.64 \pm 7.78$ * \\
\hline Acalou & $136.21 \pm 4.20 \mathrm{a}$ & $90.67 \pm 9.93 a$ & $156.97 \pm 7.71 \mathrm{a}$ * & $41.10 \pm 9.73 a$ & $155.93 \pm 6.74 a$ * \\
\hline TE 9306 & $159.79 \pm 6.99 a$ & $111.54 \pm 1.09 a$ & $117.35 \pm 25.21 \mathrm{a} n \mathrm{~s}$ & $50.37 \pm 8.08 a$ & $120.09 \pm 12.59 \mathrm{a}$ * \\
\hline Durum wheat & $148.00 \pm 7.58$ & $101.10 \pm 7.28$ & $137.16 \pm 15.71 \mathrm{~ns}$ & $45.74 \pm 5.82$ & $138.01 \pm 11.88$ *** \\
\hline \multicolumn{6}{|c|}{ Spike } \\
\hline Golia & & $123.11 \pm 19.73 a$ & $120.17 \pm 1.80 \mathrm{a} n s$ & $143.63 \pm 1.16 a$ & $163.83 \pm 13.61 \mathrm{ans}$ \\
\hline Sever & & $136.01 \pm 30.79 a$ & $112.81 \pm 8.08 \mathrm{a} n s$ & $116.16 \pm 1.39 b$ & $117.67 \pm 3.24 a \mathrm{ans}$ \\
\hline Bread wheat & & $129.56 \pm 15.39$ & $116.49 \pm 3.99 \mathrm{~ns}$ & $129.90 \pm 7.96$ & $140.75 \pm 14.50 \mathrm{~ns}$ \\
\hline Acalou & & $168.33 \pm 4.34 a$ & $115.11 \pm 15.29 a \mathrm{~ns}$ & $95.08 \pm 8.75 a$ & $145.76 \pm 8.19 \mathrm{a} n s$ \\
\hline TE 9306 & & $120.54 \pm 5.02 b$ & $105.54 \pm 1.32 \mathrm{a} n s$ & $111.36 \pm 7.88 \mathrm{a}$ & $130.57 \pm 3.16 \mathrm{a} n \mathrm{~s}$ \\
\hline Durum wheat & & $144.43 \pm 14.06$ & $110.33 \pm 6.85$ * & $103.22 \pm 6.72$ & $138.17 \pm 5.66$ ** \\
\hline & & & & \multicolumn{2}{|c|}{ Grain } \\
\hline Golia & & & & $85.58 \pm 4.37 a$ & $126.03 \pm 8.44 a \mathrm{ans}$ \\
\hline Sever & & & & $72.40 \pm 2.10 \mathrm{a}$ & $105.45 \pm 7.37 a$ * \\
\hline Bread wheat & & & & $78.99 \pm 4.29$ & $115.74 \pm 7.50 * \star$ \\
\hline Acalou & & & & $62.03 \pm 2.76 \mathrm{a}$ & $129.66 \pm 10.27 \mathrm{a}$ * \\
\hline TE 9306 & & & & $86.19 \pm 0.13 b$ & $123.47 \pm 9.88 \mathrm{a} n s$ \\
\hline Durum wheat & & & & $74.10 \pm 0.33$ & $126.56 \pm 0.07$ ** \\
\hline
\end{tabular}

Note: Each value is the mean \pm S.E. of three replicates. Different letters in the same column refer to significant differences between genotypes. Between treatments, ns, ${ }^{*},{ }^{* *}$ and ${ }^{* * *}$ refer to: non significant, $P \leq 0.05, P \leq 0.01$ and $P \leq 0.001$, respectively.

Under heat stress, during grain filling, the shoot biomass of the plants decreased about $7 \%$ in both bread wheat genotypes, but increased $4 \%$ in the durum wheat TE 9306 genotype (Fig. 1). 

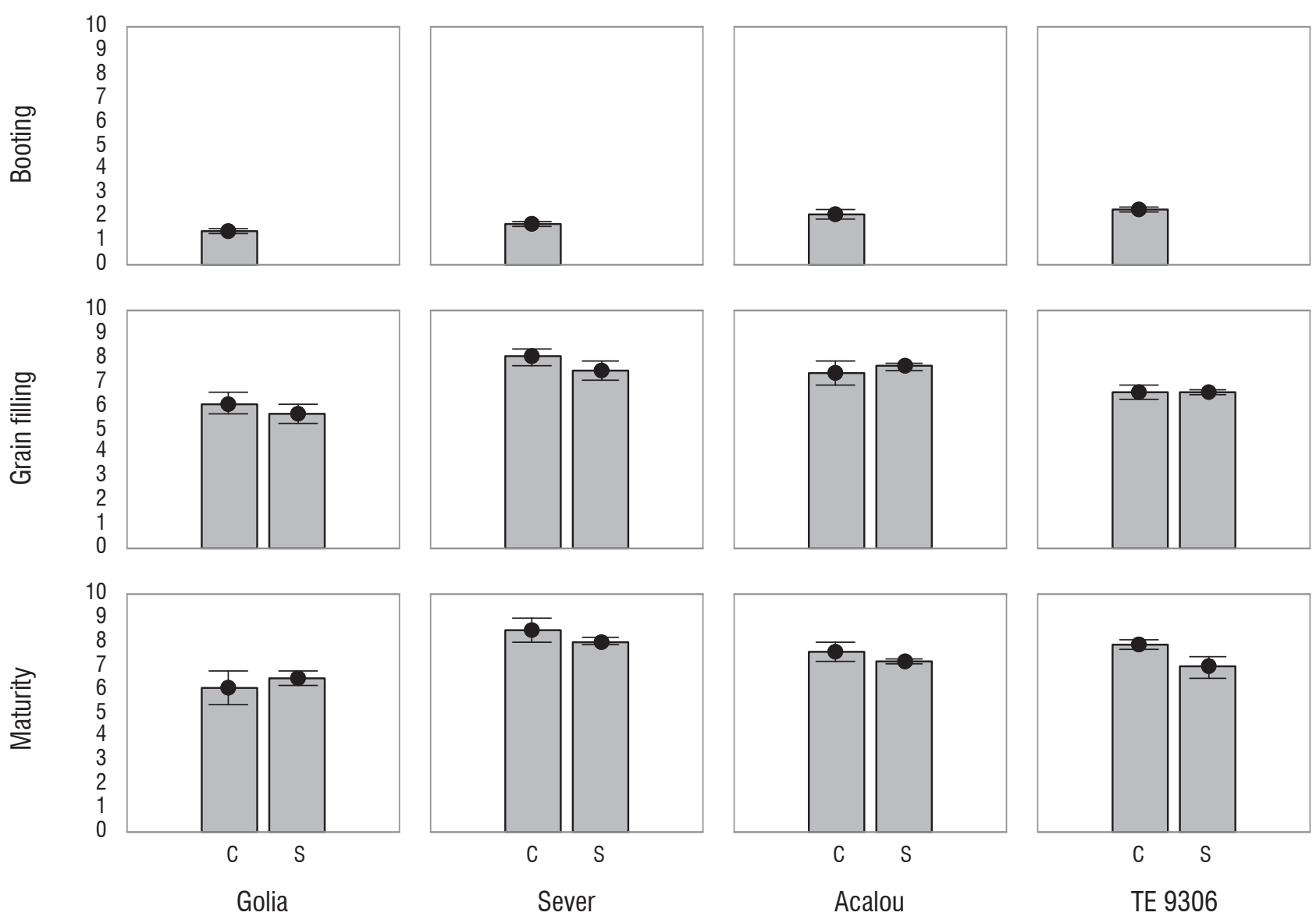

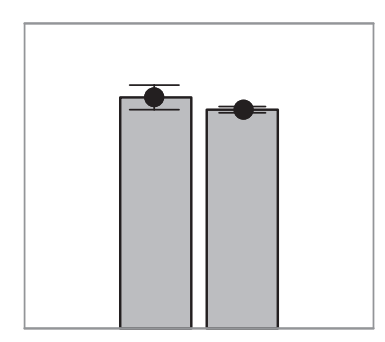

C S

Acalou

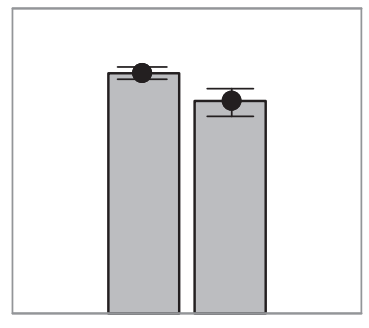

C S

TE 9306

Figure 1. Shoot wheat plants biomass ( $\mathrm{g} /$ plant), for each studied stage of growth cycle (booting, grain filling and maturity) in the two temperature treatments $(\mathrm{n}=$ 5). C - control; S - heat stress.

Sever showed a similar trend at maturity, but its biomass decreased about 6\%. Under heat stress, the biomass of the shoot of Golia, at maturity, was $7 \%$ higher. In durum wheat genotypes, at maturity, the biomass decreased $5 \%$ and $12 \%$ in Acalou and TE 9306, respectively (Fig. 1). Considering these biomasses, it was found that, under control conditions, the accumulation of $\mathrm{Cu}$ and $\mathrm{Zn}$ increased from booting to grain filling, further indicating as already pointed, an high mobility (Marschner, 1995). In this period, among the genotypes, these nutrients were translocated from the roots to the shoots in a similar proportion, being the translocation rate to the spike higher from booting onwards (Tables 3 and 4). Nevertheless, the proportion of Cu retained in the roots of Golia increased during grain filling (Table 3).
This pattern, as reported by Loneragan (1981), implicates an inhibitory effect on the excretion of Cu from root cells into the xylem and phloem saps. Moreover, under heat stress, the lower mobility of $\mathrm{Cu}$ (Table 3) is coupled to a slight drift from the aerial part of the plant to the spike of Golia and Acalou genotypes (Kabata-Pendias and Pendias, 1992). In all the heat stressed genotypes, the accumulation ratio of $\mathrm{Cu}$ in the spike was higher (Table 3), but during grain filling the decreased accumulation of $\mathrm{Cu}$ in the roots showed a more efficient $\mathrm{Cu}$ translocation to the shoots. This advantage also prevailed in Sever and TE 9306 (Table 3) since, under heat stress, total plant accumulation did not increase. Thus, in those genotypes, it must be attained that the ratio of $\mathrm{Cu}$ in the spike remains stable with high temperatures. 
Table 3. Copper total plant accumulation and respective allocation in different plant parts, on three stages of plant growth (booting - Boot, grain filling - GF and maturity - Mat) of control and heat stress bread and durum wheat genotypes.

\begin{tabular}{|c|c|c|c|c|c|c|c|c|c|c|}
\hline \multirow[t]{3}{*}{ Bread wheat genotypes } & \multicolumn{5}{|c|}{ Golia } & \multicolumn{5}{|c|}{ Sever } \\
\hline & \multicolumn{3}{|c|}{ Control } & \multicolumn{2}{|c|}{ Heat stress } & \multicolumn{3}{|c|}{ Control } & \multicolumn{2}{|c|}{ Heat stress } \\
\hline & Boot & GF & Mat & GF & Mat & Boot & GF & Mat & GF & Mat \\
\hline Total plant accumulation ( $\mu \mathrm{g}$ per Plant) & 17 & 39 & 40 & 42 & 74 & 20 & 37 & 37 & 41 & 32 \\
\hline \% Maturity & 43 & 98 & 100 & 57 & 100 & 54 & 100 & 100 & 128 & 100 \\
\hline$\%$ Plant parts & Boot & GF & Mat & GF & Mat & Boot & GF & Mat & GF & Mat \\
\hline Root & 26 & 49 & 44 & 41 & 16 & 24 & 27 & 18 & 24 & 15 \\
\hline Shoot & 74 & 29 & 11 & 22 & 41 & 76 & 43 & 44 & 33 & 33 \\
\hline Spike & & 22 & 44 & 37 & 43 & & 31 & 38 & 44 & 52 \\
\hline Grain & & & 35 & & 19 & & & 41 & & 42 \\
\hline \multirow[t]{3}{*}{ Durum wheat genotypes } & \multicolumn{5}{|c|}{ Acalou } & \multicolumn{5}{|c|}{ TE 9306} \\
\hline & \multicolumn{3}{|c|}{ Control } & \multicolumn{2}{|c|}{ Heat stress } & \multicolumn{3}{|c|}{ Control } & \multicolumn{2}{|c|}{ Heat stress } \\
\hline & Boot & GF & Mat & GF & Mat & Boot & GF & Mat & GF & Mat \\
\hline Total plant accumulation ( $u g$ per Plant) & 17 & 45 & 38 & 64 & 78 & 23 & 61 & 47 & 40 & 46 \\
\hline$\%$ Maturity & 45 & 118 & 100 & 82 & 100 & 49 & 130 & 100 & 87 & 100 \\
\hline$\%$ Plant parts & Boot & GF & Mat & GF & Mat & Boot & GF & Mat & GF & Mat \\
\hline Root & 30 & 32 & 32 & 17 & 7 & 23 & 27 & 22 & 24 & 12 \\
\hline Shoot & 70 & 28 & 23 & 27 & 39 & 77 & 26 & 19 & 27 & 28 \\
\hline Spike & & 40 & 45 & 57 & 54 & & 47 & 59 & 49 & 60 \\
\hline Grain & & & 38 & & 24 & & & 35 & & 39 \\
\hline
\end{tabular}

The ratio of total $\mathrm{Zn}$ in the grain of all the heat stressed genotypes becomes affected (Table 4). In the grains of Sever this ratio was higher due to an increasing remobilization from the shoot (Table 4), as also pointed by Garnett and Graham (2005) and Pearson and Rengel (1994) and influenced its protein composition (Peck at al., 2008; Dias et al, 2009). In the heat stressed Acalou, the difference of $\mathrm{Zn}$ accumulation in the grain (between stress and control plants) suggested a higher uptake and translocation by the roots and from the spike to the grain (Table 4).

Table 4. Zinc total plant accumulation and respective allocation in different plant parts, on three stages of plant growth (booting - Boot, grain filling - GF and maturity - Mat) of control and heat stress bread and durum wheat genotypes.

\begin{tabular}{|c|c|c|c|c|c|c|c|c|c|c|}
\hline \multirow[t]{3}{*}{ Bread wheat genotypes } & \multicolumn{5}{|c|}{ Golia } & \multicolumn{5}{|c|}{ Sever } \\
\hline & \multicolumn{3}{|c|}{ Control } & \multicolumn{2}{|c|}{ Heat stress } & \multicolumn{3}{|c|}{ Control } & \multicolumn{2}{|c|}{ Heat stress } \\
\hline & Boot & $\mathrm{GF}$ & Mat & GF & Mat & Boot & GF & Mat & GF & Mat \\
\hline Total plant accumulation ( $\mu \mathrm{g}$ per Plant) & 239 & 969 & 820 & 1051 & 1056 & 344 & 1252 & 988 & 937 & 1006 \\
\hline$\%$ Maturity & 29 & 118 & 100 & 99 & 100 & 35 & 127 & 100 & 93 & 100 \\
\hline$\%$ Plant parts & Boot & GF & Mat & GF & Mat & Boot & GF & Mat & GF & Mat \\
\hline Root & 31 & 21 & 14 & 34 & 10 & 17 & 19 & 7 & 15 & 10 \\
\hline Shoot & 69 & 40 & 15 & 25 & 22 & 83 & 38 & 34 & 32 & 29 \\
\hline Spike & & 39 & 71 & 41 & 68 & & 43 & 60 & 54 & 62 \\
\hline Grain & & & 36 & & 40 & & & 37 & & 40 \\
\hline \multirow[t]{3}{*}{ Durum wheat genotypes } & \multicolumn{5}{|c|}{ Acalou } & \multicolumn{5}{|c|}{ TE 9306} \\
\hline & \multicolumn{3}{|c|}{ Control } & \multicolumn{2}{|c|}{ Heat stress } & \multicolumn{3}{|c|}{ Control } & \multicolumn{2}{|c|}{ Heat stress } \\
\hline & Boot & GF & Mat & GF & Mat & Boot & GF & Mat & GF & Mat \\
\hline Total plant accumulation ( $\mu \mathrm{g}$ per Plant) & 342 & 1023 & 692 & 1004 & 1068 & 416 & 873 & 792 & 793 & 950 \\
\hline$\%$ Maturity & 49 & 148 & 100 & 94 & 100 & 53 & 110 & 100 & 83 & 100 \\
\hline \% Plant parts & Boot & GF & Mat & GF & Mat & Boot & GF & Mat & GF & Mat \\
\hline Root & 16 & 5 & 13 & 10 & 8 & 12 & 11 & 8 & 10 & 7 \\
\hline Shoot & 84 & 31 & 13 & 39 & 30 & 88 & 28 & 15 & 30 & 27 \\
\hline Spike & & 63 & 75 & 52 & 62 & & 60 & 77 & 60 & 66 \\
\hline Grain & & & 40 & & 45 & & & 45 & & 50 \\
\hline
\end{tabular}


Acknowledgements: The authors wish to thank to Professor Doctor Ana Luísa Fernando (GDEH, Faculdade de Ciências e Tecnologia, Universidade Nova de Lisboa, Portugal), for technical assistance.

\section{REFERENCES}

Agrawal V, Sharma K (2006) Phytotoxic effects of $\mathrm{Cu}, \mathrm{Zn}, \mathrm{Cd}$ and $\mathrm{Pb}$ on in vitro regeneration and concomitant protein in Holarrpena antidysenterical, Biol. Plant. 50: 307-310.

Bergmann W (1992) Nutritional disorders of plants: development, visual and analytical diagnosis, New York, Gustav Fischer Verlag Jena.

Blumenthal CS, Bekes F, Batey IL, Wrigley CW, Moss HJ, Mares DJ, Barlow EWR (1991) Interpretation of grain quality results from wheat variety trials with reference to high temperature stress. Aust. J. Agr. Res. 42: 325-334.

Caley CY, Duffus CM, Jeffcoat B (1990) Effects of elevated temperature in developing wheat grains. Aust. J. Plant Physiol. 17: 431-439.

Chinoy JJ (1947) Correlation between yield of wheat and temperature during ripening of grain. Nature 159: 442-444.

Chowdhury SI, Wardlaw $\operatorname{IF}(1978)$ The effect of temperature on kernel development in cereals. Aust. J. Agr. Res. 29: 205-223.

Davis KR, Peters LJ, Cain RF, Letorneau D, McGinnis J (1984) Evaluation of the nutrient composition of wheat. III. Minerals, Cereal Foods World 29 : 246-248.

Dias AS, Bagulho AS, Lidon FC (2008). Ultrastructure and biochemical traits of bread and durum wheat grains under heat stress. Braz. J. Plant Physiol. 20: 323-333.

Dias AS, Barreiro MG, Campos PS, Ramalho JC, Lidon FC (2009). Wheat dellular membrane thermotolerance under heat stress. J. Agron. Crop Sci. in press, DOI: 10.1111/j.1439-037X.2009.00398.x.

Dias AS, Lidon FC (2009). Evaluation of grain filling rate and duration in bread and durum wheat, under heat stress after anthesis. J. Agron. Crop Sci.,195: 137-147.

Dupont FM, Altenbach SB (2003) Molecular and biochemical impacts of environmental factors on wheat grain development and protein synthesis. J. Cereal Sci. 38:133-146.

Garnett GP, Graham RD (2005). Distribution and remobilization of iron and copper in wheat. Annals of Botany 95: 817-826.

Jenner CF (1991) Effects of exposure of wheat ears to high temperature on dry matter accumulation and carbohydrate metabolism in the grain of two cultivars. II. Carry-over effects. Aust. J. Plant Physiol. 18: 179-190.

Jenner CF (1994) Starch synthesis in the kernel of wheat under high temperature conditions. Aust. J. Plant Physiol. 21: 791-806.
Kabata-Pendias A, Pendias H (1992) Trace Elements in Soils and Plants, $2^{\text {nd }}$ ed., Boca Raton: CRC Press.

Khurama NC, Chatterjee C (2000) Deficiency of manganese is alleviated more by low $\mathrm{Zn}$ than low copper in wheat. Comm. Soil Sci. Plant Anal. 31:26172625.

Loneragan JF (1981) Distribution and movement of copper in plants, Copper in soils and plants, Loneragan JF, Robson AD, Graham RD, Eds, p. 165, New York: Academic Press.

Maçãs B, Gomes MC, Dias AS, Coutinho J (2000) The tolerance of durum wheat to high temperatures during grain filling, Options Méditerranéennes. Durum wheat improvement in the Mediterranean region: new challenges, Royo C, Nachit MM, Di Fonzo N, Araus JL, Eds, pp. 257-261, Zaragoza, Spain, CIHEAM.

Marschner H (1995) Functions of mineral nutrients: Micronutrients, Mineral Nutrition of higher plants, $2^{\text {nd }}$ ed., Marschner, H., Ed., pp. 313-364, London, Academic Press.

Moore DP (1972) Mechanisms of micronutrient uptake by plants, Micronutrients in Agriculture, Mortvedt JJ, Giordano PM, Lindsay WL Eds., Madison, Wisconsin: Soil Science Society of America.

Nicolas ME, Gleadow RM, Dalling MJ (1984) Effects of drought and high temperature on grain growth in wheat. Aust. J. Plant Physiol. 11: 553-566.

Pearson JN, Rengel Z (1994). Distribution and remobilization of Zn and Mn during grain development in wheat. J. Exp. Botany 45: 1829-1835.

Peck AW, McDonald GK, Graham RD (2008). Zinc nutrition influences the protein composition of flour in bread wheat (Triticum aestivum L.). J. Cereal Sci. 47: 266-274.

Randall PJ, Moss, HJ (1990) Some effects of temperature regime during grain filling on wheat quality. Aust. J. Agr. Res. 41: 603-617.

Shpiler L, Blum A (1986) Differential reaction of wheat cultivars to hot environments, Euphytica 35: 483-492.

Sofield I, Evans LT, Cook MG, Wardlaw IF, Factors influencing the rate and duration of grain filling in wheat. Aust. J. Plant Physiol. 4: 785-797.

Stone PJ, Savin R, Wardlaw IF, Nicolas ME (1995) The influence of recovery temperature on the effect of a brief heat shock on wheat. I. Grain growth. Aust. J. Plant Physiol. 22: 945-954.

Vandecasteele C, Block CB (1993) Modern methods for trace element determination, Chichester: John Wiley \& Sons.

Wardlaw IF, Dawson IA, Munibi P, Fewster R (1989) The tolerance of wheat to high temperatures during reproductive growth. I. Survey procedures and general response patterns. Aust. J. Agr. Res. 40:1-13.

Wardlaw IF, Wrigley CW (1994) Heat tolerance in temperate cereals: an overview. Aust. J. Plant Physiol. 21: 695-703.

Wheeler DM, Power IL (1995) Comparison of plant uptake and plant toxicity of various ions in wheat, Plant Soil 172: 167-173.

Yläranta T, Jansson H, Sippola J (1979) Seasonal variation in microcontents of wheat. Ann. Agri. Fenniae 18: 218. 